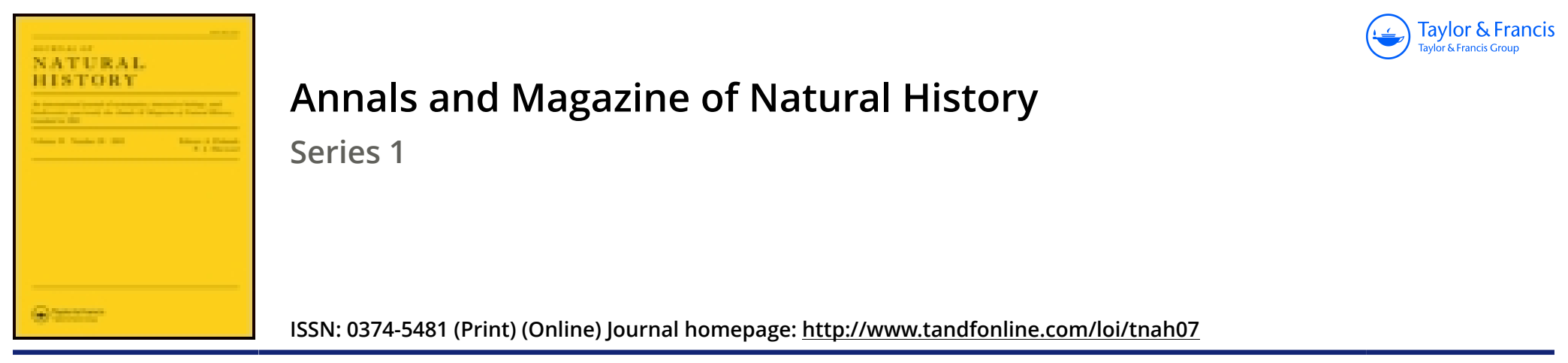

\title{
LI.-The Physical Agents of Temperature, Humidity, Light, and Soil, considered as developing Climate, and in connexion with Geographic Botany
}

\author{
Richard Brinsley Hinds Esq., Surgeon R.N.
}

To cite this article: Richard Brinsley Hinds Esq., Surgeon R.N. (1842) LI._-The Physical Agents of Temperature, Humidity, Light, and Soil, considered as developing Climate, and in connexion with Geographic Botany, Annals and Magazine of Natural History, 9:60, 469-475, DOI: $10.1080 / 03745484209445366$

To link to this article: http://dx.doi.org/10.1080/03745484209445366

曲 Published online: 04 Dec 2009.

Submit your article to this journal $₫$

Цlll Article views: 1

View related articles $₫$ 
forations in the dead valves of Cyprina Islnudica and Pecten Islandicus; not uncommon.

The zoophytes cnumerated in the preceding catalogue were either collected during a three days' examination of the detritus thrown upon the beach at Don-Mouth after a storm in October 1841, or are the result of a diligent and almost daily search during the first fortnight of February 1842, ansong the objects brought up from deep water by the lines of the Footdee fishermen. 'To the sixty-four species cmumerated above, in all probability many more remain to be added, but, bcing about to leave the neighbourhood of the Abcrdeeenshire coast, I must leave this pleasing task to future observers.

Old $A$ berdeen, February $23,1612$.

ILI.-The Physical Agents of Temperature, Intmidity, Light, and Soil, considered as developing Climate, and in connexion with Geographic Botany. By Richa dr Brivsley Hinss, Esq., Surgeon R.N.

[Contiuued from p. 333.]

\section{Lignt.}

Ligir and heat are so intimately connected and so generally accompany each other, that the laws of one are very nearly those of the other. Both are of the utmost importance to vegetation, and it is not easy to allow a superior influence to either, each in its turn, when coming under consideration, appearing to claim priority. Light is pre-eminently active in the functions depending on the alternation of day and night, in fixing the more solid constituents, and in bestowing richness of colour and secretion.

Sir Isaac Newton, by means of the prism, separated solar light into seven distinct rays, which from their properties he called colorific. These were red, orange, yellow; green, blue, indigo and violet; and they were found to possess different degrees of refrangibility, it being greatest in the violet and least in the red. A method was now developed for explaining the numerous shades of colour in substances; black was ascribed to the absorption of all the rays, white to thcir reflection, and every variety of tint or colour was due to the partial reflection of certain rays and the absorption of all the others. More recently it has been proved by Sir David Brewster that these seven colours are resolvable into three primary rays, red, yellow and blue; orange being formed by a mixture of red and ycllow, green by yellow and blue, indigo and violet by red and 
blue, the latter receiving a slight portion of ycllow. The varied colours of flowers, fruits, and of vegetable substances generally are dependent on a peculiar and inscrutable property of their tissues, enabling them to reflect certain rays or portions of rays, the depth and richness depending on the quantity of their exposure to heat and light.

Though colour is one of the most prominent effects of light, it materially influences some of the vital functions of plants. Under it alone takes place the decomposition of carbonic acid, whereby solid carbon is bestowed on the plant, and oxygen yielded to the atmospherc. When deprived of light the tissues are extremely lax, the whole plant assumes an unhealthy longitudinal development, apparently scarching for what is so highly necessary to its economy; the proper secretions are not at all, or most sparingly, climinated, losing the customary sapid, acrid, aromatic or other propertics. Its effects on many of the leaves and flowers of warn climates are remarkable, both only expanding under its influence, and closing or folding up as this declines or is removed. Pinnate leaves are more particularly affected in this manner, and they greatly prevail in low latitudes : many flowers are liable to this, Composite present numerous instances; the Oxalidere and Mesembryanthema of Southern Africa require the full glare of the sun before they will expand their flowers, often opening only for a short period, and when a cloudy day occurs they will not unfold at all. The scarlct pimpernel (Anagallis arvensis) of our fields has received the appellation of the shcpherd's weather-glass, from the sensitiveness it betrays on the approach of a clond threatening rain, and the term appears to have been applied with much correctness. Those flowers with a contorted iestivation are eminently affected by its presence or absence.

Like temperature, the intensity of light diminishes from the equator to the poles, but not so rapidly, rather corresponding with the radiation of the sun's rays; thus in high latitudes, the light is proportionately greater for the temperature than in low, and a similar circumstance happens in alpine situations, as was observed long since by Saussure. The protracted period in northern climates at one time of the presence of light, and at another of its absence, might be supposed to affect proportionately the regetation; a flora may be expected running its course within a short period, displaying considerable vigour of growth, and after having perfected the seeds, leaving future existence entirely with them. In a somewhat lower latitude careful preparation is made to mect that portion of the year when the temperature is rigorous and light greatly remored; 
the trees shed their leaves, leaving no tender organs exposed, vitality is well shut up and preserved in the solid parts, and the perennial plants leave their roots buried within the slow conducting materials of the earth.

Light is not so essential to colours but that they are sometimes produced without it, and all which in botanical acceptation are received as such, are known to be developed without its influence; green, which is not regarded botanically as a colour, is the most rarely formed under such circumstances; but instances are to be met with, and I shall cite the rich green of the secds imbedded in the pulp of the fruit of the Jacquinia aurantiaca. Many sea-wceds, growing at depths accessible only to very subdued light, are supplied with much richness of colour, good pinks and greens being the most common. Plants will sometimes grow where they are not in the least degree exposed to light, and even in such cases they will form a small portion of chromule; their general appearance is here so changed and distorted that they are not easily recognized, the organs being irregularly developed, and losing their customary shape and outline. In a natural state the simpler organized plants are more usually found in situations feebly admitting light, as mosses, lichens, and the Alga gloioclader.

The good effects of light on the regetable kingdom are displayed in a variety of ways connected with its growth; it increases the stature and development of forest-trees, causing them to spread more, giving a greater solidity to their structure, and strength and durability to their woods. In those countries where the brilliancy of the light is not obstructed by atmospheric causes, the flowers excel in the lustre of their colours, and vegetation partakes strongly of fragrance: Lower California, though destitute of trees and almost of shrubs, has a variety of plants of the most lively colours, and both the flowers and folinge generally abound in aromatic properties. The absence here of the larger vegetation admits frecly the sun's rays; the dew-point of the atmosphere is greatly below the temperature, there being but little suspended moisture, the skies cloudless, and the soil too arid to admit of much evaporation. The vegetation, though consisting entircly of lowly plants, is exceedingly interesting from the engaging colours, peculiar structure of many of the flowers, and the individuality of the flora generally.

In one state of vegetation alone is light prejudicial ; during germination carbonic acid is given off by the seed and oxygen absorbed: this is a state of things favoured by darkness, the reverse occurring in growing plants when exposed to the 
heat and light of the sun. Ingenhouz was the first to observe this prejudicial effect of light, and the circumstance was soon confirmed by Sennebier.

\section{SoIL.}

There are several circumstances which favour the conclusion that soil is of secondary importance in its influence on the vegetable kingdom. 1. In those climates where the heat and moisture of the atmosphere are in excess, and vegetation puts on its gayest forms, it is not unusual to see the roots of the loftiest trees of the forest exposed in the beds of mountain torrents, where they have been left bare by the sudden rush of water in the rainy season. Often trees of the greatest vigour shoot upwards from the fissures of hard rocks, the roots penctrating the crevices, and to every appearance without the means of communication with anything like soil. 2. A considerable number of plants live on the surfaces of others, without drawing the least portion of nourishment from them. These are the truly epiphytic linds, and include numerous species of Orchidacea, Aroidlea, Brometia, Tillandsia; with many ferns, mosses, lichens and fungi. Their dependence scems placed chicfly in the atmosphere for the means of existence; though it is no doubt true, that when large trees become a good deal covered with many of these plants, a quintity of refuse vegetable matter collects round the points of attachment, and is made available by the plants themselves. The manner in which the bases of the leaves in Bromelia and Tillendsia sheath over each other so as to form n cup, cnables them to retain a quantity of water for a long time, and the falling leaves, portions of broken branches, flowers and fruits that have been shed, all tumbling in and mixing together, form a very turbid but nutritice mixture. Few, I imagine, will not sympathize with Dampicr, when in a similar situation, who informs us, that, when wandering in the woods and parched with thirst, he was frequently in the labit of opening a channel with his knife in the lower part of these plants, and. thus obtaining a good supply of water. Frequently dend beetles, drowned ants, and many other insects are floating on the surface, all which may make a very serviceable beverage for the vegetable kingdom, but one little likely to be palatable to man. 3. That plants generally are not conspicuous for their attachment to particular soils, is manifest from the number which will thrive in the uniform circumstances of a botanic garden; here species which have been assembled from a variety of situations are placed side by side, and grow so well, that there is cvery inducement to believe the nature of the 
soil is with them of very trifling importance. Some plants undoubtedly have predilections for particular soils, but these are exceptions to the mass of vegetation, and in some of these cases it is the property of retaining moisture or collecting heat which dircets the bias of the plant, more than any inherent peculiarity of the soil. 4. Some water plants float on the surface without any communication with the bottom, as the Lemna and many Cellulares; the marine algx, though attached, are without the least semblance of a soil to draw from, and some are of such enormous length, that it would in all probability take a long time for any nutrient matter to find its way from the root to the opposite extremity; whilst the Sargassum vulgare, if not without a root, is at lenst well able to survive a separation.

A natural soil is a very heterogeneous substance; its base might be expected to proceed from the disintegration of the predominant rock in its vicinity, and such it usually is ; many foreign materials are soon mixed with it, substances drifted by the wind, the decaying parts of vegetation, the droppings of animals, in some cases not an unimportant integrant, even occasionally the dead remains of animals themselves; but in a state of nature these latter are soon invaded by a host of beings which ere long remove every vestige of their prey. All these substances are included in the twofold division of inorganic and organic; the former being derived from the mineral world, the latter from plants and animals.

The organic portion, or mould, is that constituent of the soil which is the actual food of plants, and whilst the inorganic part acts as a mechanical agent in retaining or diffusing moisture, this is destined, after being rendered soluble by the action of the atmosphere, to furnish nourishment to regetation. As mould results chiefly from vegetable decomposition, many varieties may be distinguished according to the kind of plants furnishing it. One, well known, is found on our heaths, or in situations where the Erice have been growing, and is particularly suited for the rearing of other members of their family. The mould formed by the decay of the Eucalyptus of New Holland would scem to have such a prejudicial effect on the soil as to cxclude other vegetation, and assemblages of trec-ferns have apparently the same effect. 'The black soil at the bottom of pools and ditches of stagnant water owes its richness to the large quantity of vegetable remains in a state of rapid decomposition and rendered soluble for future nutrition.

'The different mineral productions which form the mass of our globe, regarded as to their efficiency in creating soils, have Ann. \& Mag. N. Hist. Vol. ix. 
been divided by Professor Jameson into eight classes or varieties, and whilst we borrow his ideas on this subject it will be convenient to reverse his arrangement, by commencing with those which are found most conducive to their formation.

The first class contains those substances which separate with facility into an carthy mass ; as marl, slate-clay, basaltic and volcanic tuffa. The two latter are capable of producing a very fertile soil; on the declivities of Mount Etna the veretation is luxuriant, and also in the vicinity of Vesuvius.

To the second class belong conglomerate rocks of greywacke, old red sandstone, and sandstones of various kinds, easily separable by mechanical forces and convertible into grarelly, sandy, or earthy soils.

Third class. Slaty rocks, by their natural structure casily divided and reduced to a mass, which, mixed with water, forms a paste.

In the fourth class are those rocks having a crystalline or granular texture; their cohesion not being considerable, they are easily reduced. Granite and gneiss belong here, rocks which often form a good soil, as the materials forming them are loose in their aggregation and retain a proper allowance of moisture.

Fifth class. Basalt; not very favourable to vegetation. The flora of a basalt country is usually mearre.

Sixth class. Chalk and gypsum, though without much cohesion, are not likely to produce a good soil, nor do they rendily retain moisture.

The seventh class comprises compact limestone; even when much comminuted this will not develope any good qualities, owing to the abundance of calcareous matter. A mixture with aluminous earth in some measure counteracts this excess.

In the eighth class are assembled those substances, which, by exposure to the atmosphere for long periods, undergo, if any, very trivial changes. 'They consist of vitreous lava, pure quartz, compact quartz, flinty slate, and porphyry with a siliceous base. No soil properly so called is formed by them, and the only vegetation likely to be met with in their neighbourhood are lichens, which attach themselves to the surface.

These are some of the principal rocks which lend their constituent parts towards the generation of Soil. In nature the number, by every possible admixture, becomes multiplied to infinity; but whatever may be the mineralogical condition of its structure, vegetation will not thrive in a soil having its sole origin in this source, which an experiment by Giobert admirably illustrates. The four earths, silica, alumina, lime and magnesia, were mixed together in such proportions as 
were considered to constitute a fertile soil; the compound was well watered and planted with scveral vegetables; they however would not thrive till the water was changed for the drainings of a dunghill. Plants have been placed in a variety of substances, as sulphur, pounded glass, \&c., and carefully moistened with distilled water; in this state they have existed for some time, but it is beyond all experience to suppose, that, in such a condition, they should perfect the several functions required of them by nature. It is only by a proper supply of organized matter in the soil that vegetation can proceed with vigour; some portion of this is supplicd by animals, but by far the greater and more important is yielded by plants, which is thus returning to the form and uses from which it had previously issued.

Every year brings in the alternation of its seasons chnnges in the vegetable kingdom; as soon as spring has sct in new life is given to every herb and shrub, the buds unfold, developing flowers and leaves; the former soon fade and fall, in time the fruit follows, and towards the end of summer the rising winds drive the leaves in clouds from the trees. Heavy rains now' succeed, and the broken branches, portions of shed bark and other vegetable remains, the refuse of the autumn, are soon saturated with moisture and hasten to decomposition. In countries with excessively moist climates the quantity of fallen vegetation is immensc; large trees, the noblest members of the forest, sinking under the effects of a continually moist atmosphere, literally lie in tiers, and give a footing, though often a treacherous one, for hundreds of yards without it being necessary to touch the soil. A portion of this decaying matter is dissolved by the rain-water, and penetrating the carth carries nutriment to the roots against the demands of the ensuing spring. What remains gradually mixes with the mineral constituents of the soil, and more slowly becomes subservient to the same end.

[To be continued.]

LII.-Excerpta Botanica, or abridged Extracts translated from the Foreign Journals, illustrative of, or connected with, the Botany of Great Britain. By W. A. Leighton, Eisq., B.A., F.B.S.E., \&c.

No. 10. Revisio Tiliarum. Auctore Eduardo Spach. (Ann. des Sc. Nat. vol. ii. n. s. p. 381.) [So far as respects our British species.]

TILIA, Linn.

Arbores, comî subrotundâ vel ovali, densissimâ. Cortex interior flexilis, tenax. Lignum lære. Ramuli sæpè ab auturno ad ver 